\title{
THE EFFECT OF IRON, ZINC AND ORGANIC FERTILIZER ON YIELD OF CHICKPEA (CICER ARTIETINUM L.) IN MEDITERRANEAN CLIMATE
}

\author{
Mohsen Janmohammadi ${ }^{1}$, Hedayat Abdoli ${ }^{1}$, Naser Sabaghnia ${ }^{1}$, \\ Mohammad Esmailpour ${ }^{2}$, Ahmad Aghaei ${ }^{3}$
}

${ }^{1}$ Department of Plant Production and Genetics, Faculty of Agriculture, University of Maragheh, P.O. Box 55181-83111, Maragheh, Iran

${ }^{2}$ Department of Medicinal and Aromatic Plants, Jahrom university, P.O. Box 74131-88941, Jahrom, Iran

${ }^{3}$ Department of Biology, Faculty of Science, University of Maragheh, Iran

\begin{abstract}
JANMOHAMMADI MOHSEN, ABDOLI HEDAYAT, SABAGHNIA NASER, ESMAILPOUR MOHAMMAD, AGHAEI AHMAD. 2018. The Effect Of Iron, Zinc and Organic Fertilizer on Yield of Chickpea(Cicer Artietinum L.) in Mediterranean Climate. Acta Universitatis Agriculturae et Silviculturae Mendelianae Brunensis, 66(1): 0049-0060.
\end{abstract}

Chickpea is one the most important legume crops in Mediterranean semi-arid regions and its sustainable production strongly depends on the nutrient management and water availability. Soils of these regions generally have high $\mathrm{pH}$, and low organic matter, which reduce the availability of micronutrients and led to multi-micronutrient deficiencies. For estimating the effect of integrated application of different levels of organic fertilizer (zero, $20 \mathrm{tha}^{-1}$, $40 \mathrm{t} \mathrm{ha}^{-1}$ ) and micronutrient fertilizers $(\mathrm{Zn}, \mathrm{Fe})$ on agronomic traits and yield components of chickpea, an experiment was carried out at the highland semi-arid regions in Piranshahr district ( $36^{\circ} 40^{\prime} \mathrm{N}, 45^{\circ} 08^{\prime} \mathrm{E} ; 1840 \mathrm{~m}$ ). Assessment of phenological development revealed that plants grown under control condition (no-organic and micronutrients fertilizer) had a significantly slower development. Assessment of agronomic characteristics showed that application of micronutrients fertilizer substantially increased plant height, first pod height, canopy width, number of the seed, seed weight, economic and biological yield compared to control condition. By increasing the application rate of organic fertilizer its positive effects became more impressive on growth and yield component. The best growth performance was recorded by integrated application of $40 \mathrm{th} \mathrm{h}^{-1}$ organic fertilizer and micronutrients fertilizers. However, there was no significant difference between fertilizer of Fe and Zn. Overall, the results indicated that the studied site is facing with micronutrient deficiencies and application organic fertilizer can noticeably improve the efficiency of micronutrients fertilizer. A quick and supplementary approach is therefore required for remedy of both Zn and Fe deficiencies in the short term. The finding showed that a substantial yield improvement is possible by integrated application of organic and micronutrient fertilizer.

Keywords: agronomic characteristics, balanced nutrition, integrated application, nano-micronutrients fertilizer, semi-arid region

\section{INTRODUCTION}

The chickpea (Cicer arietinum L.) also called Bengal gram or Garbanzo is the most widely produced food legume in semi-arid regions and the third largest produced food legume globally. It is grown in more than 50 countries, with more than $90 \%$ of chickpea production coming from Asia (Yadav et al., 2007). Chickpea is very valuable 
in terms of nutritional quality, it is a good source of protein, and have an important role in human diet particularly in developing countries. In terms of production and cultivated area the major producing countries are India, Pakistan, Turkey, Iran, Myanmar, Australia, Ethiopia, Canada, Mexico, and Iraq. The average yield of chickpea in Iran is lower than $500 \mathrm{~kg} \mathrm{ha}^{-1}$; while the world average yield is $900 \mathrm{~kg} \mathrm{ha}^{-1}$. Total production of chickpea in Iran was about 261,600 tons in 2014 that harvest from 598,400 ha (FAO, 2014).

However, the semi-arid areas are faced with some restrictions and this impede the achievement of potential yield. These areas are characterized by low rainfall with high spatial and temporal variability in precipitation that leading to risk of severe drought (Snyder and Tartowski, 2006). The soil organic matter content (SOM) is very low in these regions. The change and transformation of materials within SOM pools is a dynamic process that affected by climatic factors (temperature, precipitation, humidity, radiation density, etc.), soil characteristics (soil texture, available soil moisture and water saturation, water holding capacity, salinity and acidity, topography), vegetation (biomass production, growth rate) and soil biological condition (Bot and Benites, 2005; Janmohammadi, 2015). In semi-arid regions nutrient imbalance is one of the major constrictions limiting productivity of chickpea (Janmohammadi et al., 2017). However, given some of the unique characteristics of chickpeas, effort to improve its productivity under semi-arid regions should be emphasized. Among improvement possibilities, the optimal supply of nutritional requirements plays a major role.

Although the inorganic fertilizers have some benefits to sustain plant growth, they also have some weaknesses such as high possibility of leaching, high energy consumption for their production, risk of the toxic chemicals, stimulating the vegetative growth and depletion of soil water storage (Oslen, 1978). Crop nutrient uptake and crop yields are the major factors that determine optimal fertilization practices (Ju and Christie, 2011). Therefore, it is very important to apply fertilizers in an efficient way to minimize loss and to improve the nutrient use efficiency. On the other hand, low and declining soil organic matter contents pose a significant threat to soil fertility, crop productivity and economic returns in arid and semi-arid agroecosystems. Hence it seems that application of organic matter can improve the efficiency of chemical fertilizers significantly (Heng et al., 2005). In this context, there are rising evidences about the positive effects of organic fertilizers on crop production in semiarid areas, however, farmers in the region rely on short-term positive effects of chemical fertilizers to maintain crop yields, and pay little attention to maintaining soil organic matter in soils (Shirani et al., 2002; Janmohammadi 2015; Janmohammadi et al., 2016).
Current agricultural practices involve deliberately maintaining ecosystems in a highly simplified, disturbed, and nutrient-rich state. But these conditions are fragile and if the soil conditions (low SOM and nutrients imbalance) are not improved the production will be unstable. Additional crop production by balanced nutrient managements leads to larger quantities of residue that can build up soil organic matter and provide protection from erosion. Moreover, in normal soils with some organic matter content, exchangeable cations such as $\mathrm{Ca}^{2+}$ and $\mathrm{Mg}^{2+}$ link clay particles to humic acids of the organic matter, generating stable micro-aggregates which are the basis for soil structure, porosity, and internal drainage (Machado and Serralheiro, 2017). Furthermore, modern agriculture based on merely chemicals is not sustainable because of many problems such as loss of soil productivity from excessive erosion and associated plant nutrient losses, surface and ground water pollution from pesticides, fertilizers and sediments impending shortages of non-renewable resources and low farm income from high production costs (Joshi et al., 2016).

Application of organic matter to meet the nutrient requirement of crops would be an inevitable practice in years to come, particularly for resource-poor farmers. Also, ecological and environment concerns over the increased and indiscriminate use of inorganic fertilizers have made research on use of organic materials as a source of essential nutrients. However, the use of organic manures alone may not be sufficient to meet the enormous nutrient requirements of present day high yielding cultivars (Satyanarayana et al., 2002).

The long-term sustainability of many existing cropping systems in arid and semi-arid environments is questionable because of very low return of organic matter to the soil and high decomposition rate of organic matter that can lead to very low organic matter contents in soils. Therefore, large annual rates of organic inputs are required to sustain an adequate labile soil organic matter pool in cultivated area. Organic manures may increase soil fertility and thus the crop production potential possibly by changes in soils physical and chemical properties including nutrient bioavailability, soil structure, water holding capacity, cation exchange capacity, soil pH, microbial community and activity etc. (Bot and Benites, 2005; Marschner, 2012; Machado and Serralheiro, 2017). Despite the fact that micronutrients (such as $\mathrm{Zn}$ and Fe) are required in very low concentrations by plants, they are necessary for plant metabolism and growth as macronutrients. The availability and uptake of micronutrients are significantly affected by SOM application and subsequent changes in rhizosphere (Marschner, 2012).

Although the effect of micronutrient fertilizers and farmyard manure have been partially deliberate in semi-arid regions, little attention has been paid to integrated application of organic and inorganic 
micronutrient fertilizers in continuous cultivated lands with greater nutrient removal from soil. There is close relationship between the SOM and soil fertility that is defined as the capability to sustain plant productivity and maintain or enhance water and air quality (Karlen et al., 1997; Mader et al., 2002; Wang et al., 2014). To our knowledge, there are few published studies available on integrated application of micronutrient at different organic fertilizer rates on productivity of chickpea in semiarid highland region. We hypothesize that under Mediterranean semi-arid regions the expected efficiency of micronutrients fertilizers will be achieved by providing a threshold or minimum level of organic matter. The objective of the present study was therefore the examination of this hypothesis by investigating whether organic fertilizer can improve the efficiency of micronutrients in chickpea production system.

\section{MATERIAL AND METHODS}

Field experiments were carried out at an Experimental Farm around of Piranshahr, North-west of Iran $\left(36^{\circ} 40^{\prime} \mathrm{N}, 4^{\circ} 05^{\prime} \mathrm{E}\right.$; $\left.1840 \mathrm{~m}\right)$ during the 2016-2017 seasons. In terms of climate classifications, the area is located in the semi-arid temperate zone with cold winter and moderate summer. Long-term average mean air temperature for the April until August period is $17.8^{\circ} \mathrm{C}$. The average annual temperature in Piranshahr is $11.5^{\circ} \mathrm{C}$. The average of annual rainfall plus snowfall is $550 \mathrm{~mm}$ that the most of rainfall occurs in winter and spring. For soil analysis the composite soil samples were collected two weeks before planting, at a depth of $0-30 \mathrm{~cm}$. The soil was air-dried and crushed before its $\mathrm{pH}$, electrical conductivity (EC), and saturation percentage were evaluated. Then total organic carbon (using the Walkley and Black method, which involves sulphuric acid), total nitrogen (using the Kjeldahl method), available phosphorus (using the Olsen procedure), available potassium (after extraction with ammonium acetate) and total neutralizing value (TNV) were determined following the method as described by Jackson (1973) Tandon (1995) were measured.

The soil texture of the experimental site is clay loam, comprising of $26 \%$ sand, $333 \%$ silt and $41 \%$ clay. It contains $0.36 \%$ organic matter (OM) with a $\mathrm{pH}$ of 7.35 , with electrical conductivity $(E C)=1.13 \mathrm{ds} \mathrm{m}^{-1}, \mathrm{TNV}=43.8 \%, 0.12 \%$ nitrogen $(\mathrm{N}), 21.61$ available phosphorus $\left(\mathrm{mg} \mathrm{kg}^{-1}\right)$, and $247 \mathrm{mg} \mathrm{kg}^{-1}$ available potassium (K). The previous crop was safflower (Triticum aestivum L.). After deep ploughing at autumn of 2016 the field was abandoned as bare fallow during the winter. Soil disked tow times before the planting and seeds were hand planted on 2 April, 2017. The Kabuli Chickpea (Cicer arietinum L.) cultivar "Hashem" was used in the experiment. The obtained seeds were propagated in isolated fields under full irrigated condition, according to Sabaghnia et al. (2015), in northwest of Iran. Before the start of the experiment seeds were treated with a mixture of carboxin (5, 6-dihydro-2-methyl-1,4-oxathiin-3carboxamide) and actellic (a.i. pirimiphos methyl) at $(2: 1)$ to minimize the probability of seed- and soil-borne diseases.

The experimental design was Split block with a control in randomized complete block design with four replications. Main plot treatments consisted of three farmyard manure rates: 0,20 and $40 \mathrm{t} \mathrm{ha}^{-1}$. Sub plot treatments were two levels of micronutrient ( $\mathrm{Zn}$ and Fe; $2 \mathrm{~kg} \mathrm{ha}^{-1}$ ). The subplot treatments were randomly assigned independently within each main plot. Control or check plot received no treatments. Micronutrients fertilizers (containing $18.0 \%$ and $13.0 \%$ water soluble iron and zinc) was divided into three equal parts; the first part of the micronutrients was applied at planting time, second and third parts used at 6-8 leaves and flowering stages (R2: full bloom, most flowers are open). The micronutrient fertilizers were used as fertigation by the incorporation of fertilizers into the irrigation water. By adopting this approach, readily soluble nutrients can be supplied directly to the root volume thereby maximizing nutrient efficiency and minimizing over fertilization and leakage to underground water with possible damage to the environment. Chemical properties of organic fertilizer included CEC $=33.51 \mathrm{meq} / 100 \mathrm{~g}, 0.75 \%$ of total N, $0.54 \%$ of available $\mathrm{P}$ and $1.23 \%$ of available K, $480 \mathrm{mg} \mathrm{kg}^{-1} \mathrm{Fe}, 231 \mathrm{mg} \mathrm{kg}^{-1} \mathrm{Zn}, \mathrm{pH} 6.78$.

Seeds of chickpea were hand planted on 12 April in five row plots, $5 \mathrm{~m}$ long with spacing of $0.5 \mathrm{~m}$ between rows. Two seeds were sown per hill. The field was immediately irrigated after planting to ensure uniform germination. After germination, the plants were thinned to one seedling per hill to obtain about 36 plants per $\mathrm{m}^{-2}$. Weeds were controlled over the growth period with hand hoeing. A small terrace $(1.5 \mathrm{~m})$ was considered in the interspaces to prevent contamination by surface run-off containing fertilizer.

Timely and efficient monitoring of crop phenology at a high spatial resolution are crucial for the precise and effective management. Crop phenology was monitored at 1-2 day intervals throughout the season and three stages of crop development were highlighted. Those three stages include: flowering ( $50 \%$ of the plants had one open flower at any node on the main stem in any plot); yellowing (50\% of leaves and pod lost the green color and became the yellow) and harvest maturity (95\% of pods have obtained their mature color in any plot).

No irrigation was applied during the vegetative phase and plants were grown under rainfed condition and only three supplemental irrigations applied during the reproductive stage (flowering, podding and seed filling stages). The amount of irrigation water was calculated to restore water content in the root zone to field capacity. Depth of net irrigation water fraction was $\sim 110 \mathrm{~mm}$. All necessary cultural practices and plant protection 
measures were followed uniformly for all the plots during the entire period of experimentation. Canopy width is a measure of the footprint or area of the canopy expressed as a diameter. The canopy width measurement is the average length of two lines across the canopy area. The first measurement is made along the longest axis of the canopy from one edge to the opposite edge. The plants were harvested at physiological maturity and morphological traits such as plant height, total number of pods, filled and unfilled pods per plant, number of grains per pod, number of grains per plant and 100 - grain weight were recorded on 15 randomly selected plants in each plot. Grain and biological yield was determined by harvesting the middle three rows of each plot. Harvest index was calculated as the ratio of seed yield to aboveground dry matter at maturity. Data on agro-morphological traits were subjected to the analysis of variance (ANOVA) using the computer software SAS 9.1. The LSD test at $5 \%$ level of probability was used to test significant main effects. Principal components analysis is a mathematical procedure used to classify a large number of variables (items) into major components and determine their contribution to the total variation. The first principal component is accounted for the highest variability in the data, and each succeeding component accounts for the highest remaining variability as possible. The principal components analysis (PCA) was used based on Everitt and Dunn (1992).

I: Effect of organic and micronutrient fertilizers on some morphological traits of chickpea (Cicer artietinum L.) in Mediterranean climate

\begin{tabular}{|c|c|c|c|c|c|c|c|c|c|}
\hline Micronutrient & PH & FPH & DF & VP & CW & DY & DM & PFW & PDW \\
\hline & $*$ & ns & ns & ns & ns & ns & ns & ns & $*$ \\
\hline Zn & $39.11^{\mathrm{a}}$ & $11.55^{\mathrm{a}}$ & $58.77^{a}$ & $50.55^{\mathrm{a}}$ & $28.55^{\mathrm{a}}$ & $74.33^{\mathrm{a}}$ & $86.44^{a}$ & $41.33^{a}$ & $26.44^{b}$ \\
\hline $\mathbf{F e}$ & $37.11^{\mathrm{b}}$ & $11.22^{\mathrm{a}}$ & $51.77^{a}$ & $48.55^{\mathrm{a}}$ & $28.40^{\mathrm{a}}$ & $72.88^{\mathrm{a}}$ & $85.11^{\mathrm{a}}$ & $41.24^{a}$ & $28.00^{\mathrm{a}}$ \\
\hline Organic fertilizer & $*$ & $*$ & ns & $*$ & $* *$ & ns & ns & $* *$ & $* *$ \\
\hline 0 & $36.00 \mathrm{c}$ & $12.33^{\mathrm{a}}$ & $56.83^{a}$ & $48.66^{\mathrm{b}}$ & $27.16^{\mathrm{b}}$ & $72.66^{\mathrm{a}}$ & $85.66^{a}$ & $37.50^{c}$ & $19.83^{c}$ \\
\hline 20 tha $^{-1}$ & $37.50^{\mathrm{b}}$ & $11.66^{\mathrm{b}}$ & $50.83^{a}$ & $49.33^{\mathrm{ab}}$ & $28.20^{\mathrm{b}}$ & $74.16^{\mathrm{a}}$ & $85.50^{a}$ & $40.00^{\mathrm{b}}$ & $27.66^{\mathrm{b}}$ \\
\hline 40 tha $^{-1}$ & $40.83^{a}$ & $10.16^{\mathrm{c}}$ & $58.16^{a}$ & $50.66^{\mathrm{a}}$ & $30.83^{a}$ & $74.00^{\mathrm{a}}$ & $86.16^{a}$ & $46.33^{a}$ & $34.16^{a}$ \\
\hline control & $*$ & $* *$ & ns & $*$ & $* *$ & $*$ & $*$ & $* *$ & $* *$ \\
\hline $\mathbf{M} \times \mathbf{O}$ & ns & ns & ns & ns & ns & ns & $*$ & ns & ns \\
\hline CV\% & 9.42 & 7.81 & 6.41 & 4.09 & 12.23 & 6.84 & 1.53 & 14.23 & 5.47 \\
\hline
\end{tabular}

$\mathrm{PH}=$ plant height at maturity (cm), FPH: firs pod height (cm), DF: days to 50\% flowering, VP: vegetative period (day), CW: canopy width, DY: day to yellowing, DM: days to maturity, PFW: plant fresh weight (g), PDW: plant dry weight (g). M = micronutrient, $\mathrm{O}=$ organic fertilizer, $\mathrm{M} \times \mathrm{O}=$ interaction effect of micronutrient and organic fertilizer. $\mathrm{CV}=$ coefficient of variance. NS = Not significant, $*$ = Significant at $5 \%$ level of probability, ${ }^{* *}=$ Significant at $1 \%$ level of probability. Mean values of the same category followed by different letters are significant at $\mathrm{p} \leq 0.05$ level.

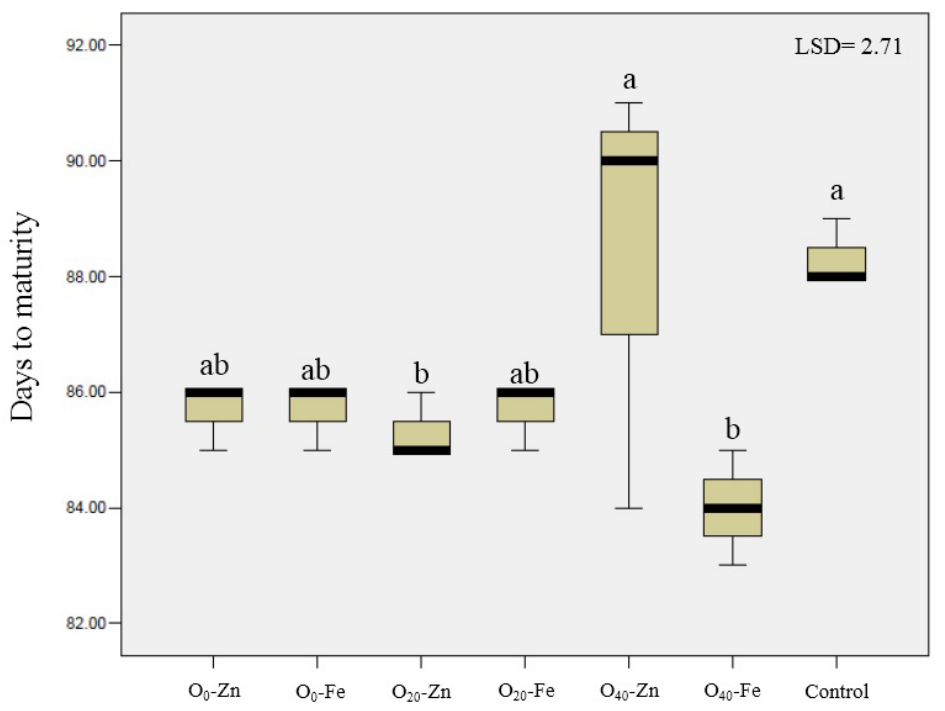

1: The effects of organic fertilizer and micronutrients on time of the maturity in chickpea plant grown in semi-arid highland region.

$\mathrm{O}_{0}$ : without organic fertilizer, $\mathrm{O}_{20}: 20$ that $a^{-1}$ organic fertilizer, $\mathrm{O}_{40}: 40$ t hat $a^{-1}$ organic fertilizer. Control: without application of organic and micronutrients fertilizers. The cap bar refer to Standard Error. The columns with the different letters are statistically different at the $\mathrm{P}<0.05$ level. LSD: least significant difference. 


\section{RESULT}

Analysis of Variance (ANOVA) of morphological and phenological traits are shown in Tab. I. Assessment of plant height showed that organic fertilizer affected this trait significantly $(\mathrm{P}<0.05)$ and the tallest plants obtained by application of $40 \mathrm{t} \mathrm{ha}^{-1}$ organic fertilizer. Also the effect of micronutrient on plant height was significant $(P<0.05)$ so that the plants grown by $\mathrm{Zn}$ had The highest height. The height of first pod affected by organic fertilizer significantly $(\mathrm{P}<0.05)$ so that the application of organic fertilizer considerably increased the height of first pod.

Number of the days to $50 \%$ flowering was not affected by micronutrients and organic fertilizer. However, the length of vegetative period (days from swing to early bloom; when the first flowers are opened) noticeably influenced by organic fertilizer and plants grown under high level of organic fertilizer had a longer vegetative period (Tab. I). Although the application of micronutrient increased the length of vegetative period in comparison with control, there was no significant difference between plants grown by $\mathrm{Fe}$ and $\mathrm{Zn}$ fertilizers. Evaluation of the canopy with showed that plants lateral growth increased by application of $40 \mathrm{t} \mathrm{ha}^{-1}$ organic fertilizer significantly $(\mathrm{P}<0.01)$. However, no significant difference was observed between $\mathrm{Fe}$ and $\mathrm{Zn}$ application. Assessment of the yellowing (reaching to stage $\mathrm{R}_{7}$ when the leaves start to yellow and $50 \%$ of pods are yellow) revealed that none of the treatments have a significant effect on this trait. The interaction effect of organic fertilizer $\times$ micronutrients was significant for days to maturity. Mean comparison of combined treatments for days to maturity showed that the difference between micronutrients was more pronounced under high organic fertilizer condition. The latest maturity was observed for plant grown under control condition and $\mathrm{O}_{40}$ - Zn (application $40 \mathrm{tha}^{-1}$ organic fertilizer along with Zn) (Fig. 1).

Plant fresh weight meaningfully responded to organic fertilizer so that application of organic fertilizer increased the plant fresh weight significantly (Tab. I). Although the application of micronutrients increased the plant fresh weight compared with control, there was no significant difference between plants grown by Fe and Zn. Evaluation of plant dry weight showed that application Fe increased this trait by $6 \%$ compared with plant grown by $\mathrm{Zn}$. Also results revealed that with increasing use of organic fertilizer plant dry weight linearly increased.

Evaluation of the seed number per plant showed that the interaction effect of organic fertilizer $\times$ micronutrients was significant for this trait (Tab. II). Although the application of the micronutrient increased the seed number, their positive influence significantly increased by organic fertilizer application. The highest seed number was recorded for plants grown under $\mathrm{O}_{40}-\mathrm{Zn}$ and $\mathrm{O}_{40}-\mathrm{Fe}$ (Fig. 2). The lowest seed number was recorded under control condition (no application of micronutrients and organic fertilizer). Seed number per pod also increased by application of $40 \mathrm{t} \mathrm{ha}^{-1}$ organic fertilizer significantly (Tab. II). Seed weight per plant affected by micronutrient fertilizers $(\mathrm{P}<0.05)$ so that the plant grown by Fe showed better performance. Also, application of the organic fertilizer improved the seed yield significantly. The heaviest seeds were recorded for plants grown under application of $40 \mathrm{tha}^{-1}$ organic fertilizer (Tab. II). However, micronutrients application had no significant effects on seed weight.

ANOVA showed that number of the pod per plant considerably affected by both factors.

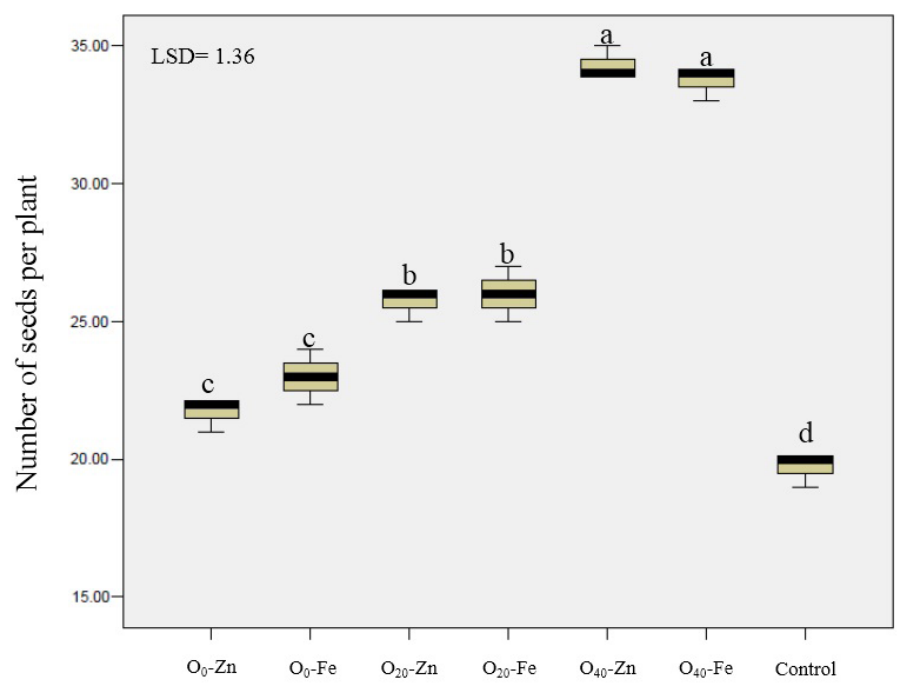

2: The effects of organic fertilizer and micronutrients on number of the seed in chickpea plants grown in semi-arid highland region. O0: without organic fertilizer, O20: 20 tha-1 organic fertilizer, O40: 40 tha-1 organic fertilizer. Control: without application of organic and micronutrients fertilizers. 
The lowest pod was recorded for plants grown under control condition. Although there was no significant difference between pod number of the plants grown by $\mathrm{Fe}$ and $\mathrm{Zn}$, by increasing the application rate of organic fertilizers pod number significantly increased (Fig. 2). ANOVA showed that the interaction effect of organic fertilizer $\times$ micronutrients was significant for empty pod per plant. The lowest empty pod was recorded for plants grown under application of $40 \mathrm{tha}^{-1}$ organic fertilizer. Mean comparison of micronutrients showed that plant grown by application Fe had lower empty pod than plants grown by $\mathrm{Zn}$. The highest empty pod number recorded for plant grown under control condition (Fig. 3). Seed yield affected by micronutrient and organic fertilizer. The mean comparison of seed yield between combined treatments showed that the highest value was obtained by combined application of $40 \mathrm{tha}^{-1}$ organic fertilizer and micronutrients. Although the effect of $\mathrm{Zn}$ was more prominent than $\mathrm{Fe}$ under no-application of organic fertilizer, there was no significant difference between micronutrient under organic fertilizer application (Fig. 4).

However, the assessment of harvest index showed that application of micronutrient and organic fertilizer induced the vegetative growth and decreased the harvest index. The lowest value of harvest index was recorded for plants grown under application of $20 \mathrm{t} \mathrm{ha} \mathrm{H}^{-1}$ organic fertilizer. The highest amount of harvest index was recorded for plants grown under control condition (Fig. 5). Evaluation of straw yield revealed that under no application of organic fertilizer condition plant grown by Fe produced higher amount of biological yield

II: Impact of organic manure and micronutrient on yield components of chickpea (Cicer artietinum L.) in Mediterranean climate

\begin{tabular}{|c|c|c|c|c|c|c|c|c|c|}
\hline Micronutrient & SNP & SPP & SWP & HSW & PNP & EPP & SY & HI & STW \\
\hline & ns & ns & $*$ & ns & $*$ & ns & * & ns & $*$ \\
\hline $\mathbf{Z n}$ & $27.22^{\mathrm{a}}$ & $0.818^{a}$ & $6.48^{b}$ & $33.33^{a}$ & $25.66^{\mathrm{a}}$ & $2.77^{\mathrm{a}}$ & $1097^{\mathrm{b}}$ & $32.11^{\mathrm{a}}$ & $3488^{b}$ \\
\hline Organic fertilizer & $* *$ & $* *$ & $* *$ & $* *$ & $* *$ & $* *$ & $* *$ & $*$ & $* *$ \\
\hline 0 & $22.33^{c}$ & $0.77^{\mathrm{b}}$ & $5.34^{c}$ & $31.50^{c}$ & $22.50^{c}$ & $3.50^{\mathrm{a}}$ & $869^{c}$ & $35.06^{\mathrm{a}}$ & $2500^{c}$ \\
\hline $40 \mathrm{tha}^{-1}$ & $34.00^{\mathrm{a}}$ & $0.86^{\mathrm{a}}$ & $8.21^{\mathrm{a}}$ & $35.00^{\mathrm{a}}$ & $30.50^{\mathrm{a}}$ & $1.04^{b}$ & $1442^{\mathrm{a}}$ & $32.84^{\mathrm{a}}$ & $4400^{\mathrm{a}}$ \\
\hline control & $*$ & $*$ & $*$ & $* *$ & $* *$ & $* *$ & $* *$ & $*$ & $* *$ \\
\hline $\mathbf{M} \times \mathbf{O}$ & $*$ & ns & ns & ns & $*$ & $*$ & $*$ & $*$ & $*$ \\
\hline CV\% & 9.38 & 7.08 & 12.14 & 8.10 & 6.44 & 3.21 & 7.92 & 10.38 & 8.54 \\
\hline
\end{tabular}

SNP: seed number per plant, SPP: seed number per pod, SWP: seed weight in plant, HSW: hundred seed weight (g), PNP: pod number per plant, EPP: empty pod per plant, SY: seed yield ( $\mathrm{kg}$ ha - 1), HI: harvest index (\%), STW: straw yield ( $\mathrm{kg} \mathrm{ha}-1$ ). $\mathrm{M}=$ micronutrient, $\mathrm{O}=$ organic fertilizer, $\mathrm{M} \times \mathrm{O}=$ interaction effect of micronutrient and organic fertilizer. $\mathrm{CV}=$ coefficient of variance. NS $=$ Not significant, ${ }^{*}=$ Significant at $5 \%$ level of probability, ${ }^{* *}=$ Significant at $1 \%$ level of probability. Mean values of the same category followed by different letters are significant at $p \leq 0.05$ level.

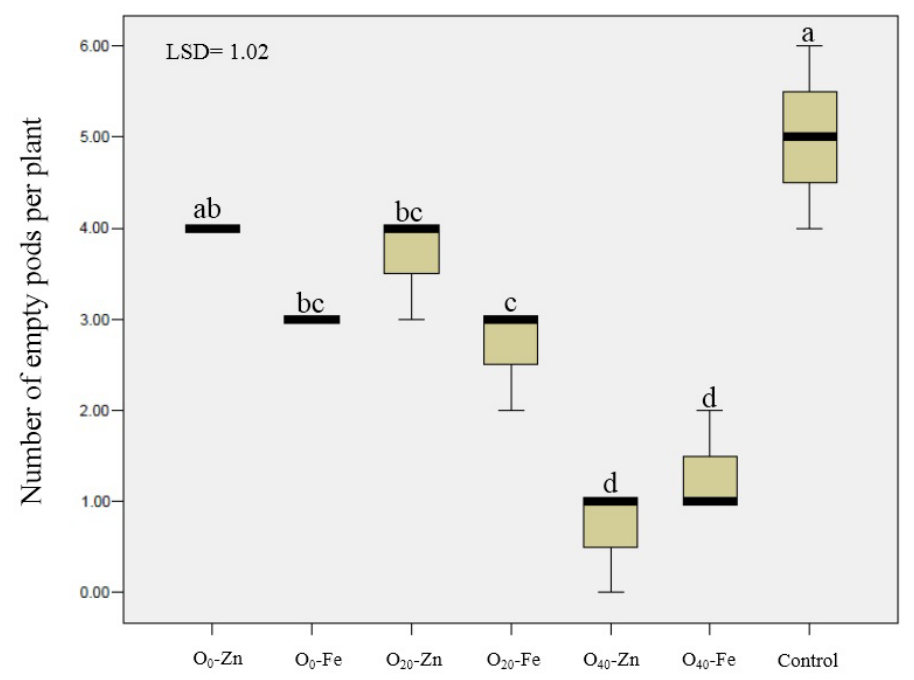

3: The effects of organic fertilizer and micronutrients on number of the empty pods in chickpea plant grown in semi-arid highland region. O0: without organic fertilizer, O20: 20 t ha - 1 organic fertilizer, O40: 40 tha - 1 organic fertilizer. Control: without application of organic and micronutrients fertilizers 
compared to $\mathrm{Zn}$ application condition. This trend also was observable under application of $20 \mathrm{tha}^{-1}$ organic fertilizer. However, the best performance was recorded for plant grown under $\mathrm{O}_{40}-\mathrm{Zn}$. Result indicated that micronutrient superiority considerably varies according to the amount of available organic material in the soil.

Principal component analysis (PCA) was carried out to recognize the contribution of components to variations. The Scree plot of the PCA (Fig. 6) shows that the first three eigenvalues correspond to the whole percentage of the variance in the dataset. The first principal component (PCl) is seed yield and yield components that explained $65 \%$ of total variability. The traits that contributed more positively to $\mathrm{PCl}$, plant height, canopy width, plant fresh weight, pod number per plant and biological yield. The second principal component (PC2) explains $21 \%$ of total variability and among the property vectors of PC2 phenological traits have higher values. The third principal component (PC3) was related harvest index and explain about $7 \%$ of total variability.

In the Fig. 7, the most prominent relations are: a strong positive association among seed weight, plant fresh weight, plant height, canopy width, straw yield, pod number per plant and seed yield as indicated by the steep angles close to zero between their vectors $(r=\cos 0=+1)$. Also there was a strong positive correlation between

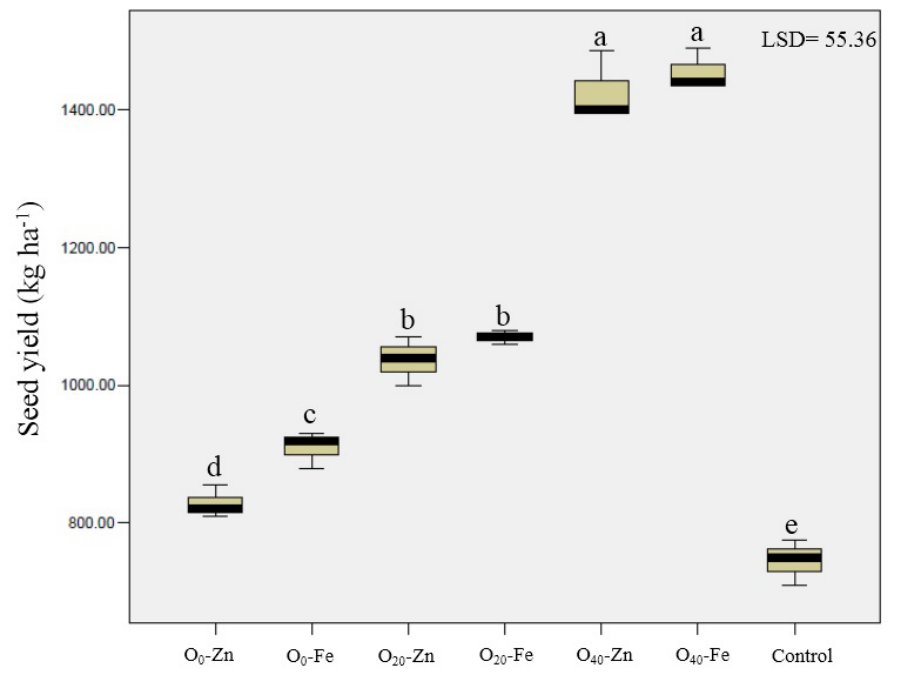

4: The effects of organic fertilizer and micronutrients on seed yield of chickpea plant grown in semi-arid highland region. O0: without organic fertilizer, O20: 20 tha - 1 organic fertilizer, O40: 40 tha - 1 organic fertilizer. Control: without application of organic and micronutrients fertilizers.

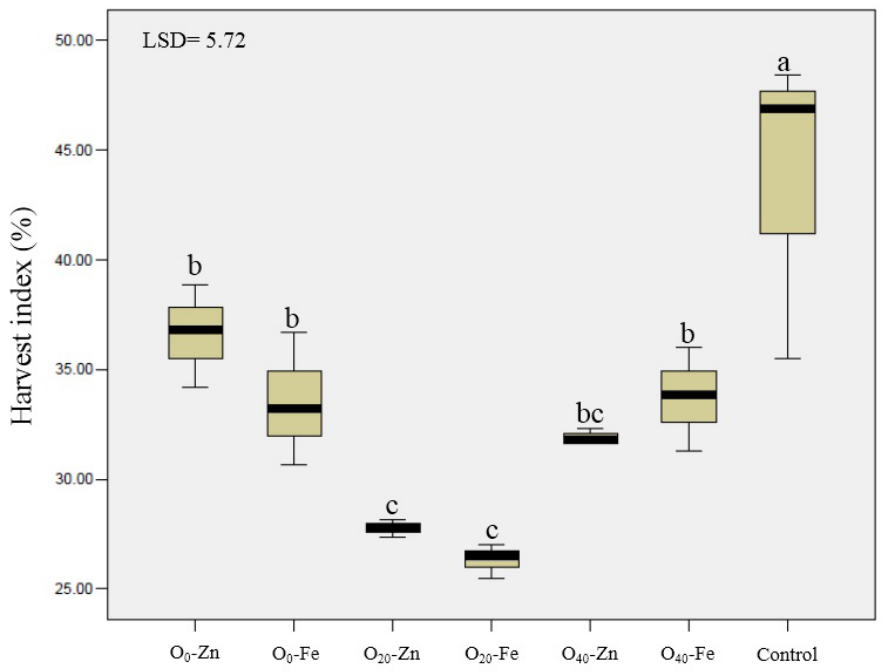

5: The effects of organic fertilizer and micronutrients on time of the maturity in chickpea plant grown in semi-arid highland region. O0: without organic fertilizer, O20: 20 tha - 1 organic fertilizer, O40: 40 tha - 1 organic fertilizer. Control: without application of organic and micronutrients fertilizers. 
phenological traits and seed number per pod. There was a negative correlation between first pod height, empty pod numbers and seed yield as indicated by the open obtuse angles between their vectors $(r=\cos 180=-1)$. There was no significant correlation between day to flowering and seed yield as indicated by the near perpendicular vectors $(r=\cos 90=0)$.

To better recognizing the similarity of combined treatments in affecting the agronomic traits the treatments are displayed in clusters (Fig 8). Cluster I consisted of micronutrient application under no-application of organic fertilizer $\left(\mathrm{O}_{0}-\mathrm{Zn}\right.$ and $\mathrm{O}_{0}-\mathrm{Fe}$ ). Cluster II consisted of control (noapplication of micronutrient and organic fertilizer) that plant showed the poorest performance. Cluster III consisted of micronutrient application along with use of $20 \mathrm{tha}^{-1}$ organic fertilizer. Cluster IV consisted of micronutrient application along with utilization of $20 \mathrm{t} \mathrm{ha}^{-1}$ organic fertilizer. Clustering results point to the very high importance of organic fertilizer in the studied area. Micronutrient fertilizers efficiency in soils and crops can be affected by different fertilization practices.

\section{DISCUSSION}

The finding revealed that organic fertilizer considerably increased the plant growth characteristics such as plant height, canopy width and plant fresh weight. Also it affected the plant phenology so that plants received the organic fertilizer showed a longer vegetative growth period. In semi-arid region with sufficient irrigation a long vegetative growth period can resulted in increased the leaf area and subsequently enhance the supply of photoassimilate for growing reproductive meristems. The result showed that aapplication of organic fertilizer, especially in large quantities, could affect the source-sink relationship. Within a plant, the "source" may be defined as a photosynthesizing tissue or organ with export of carbon skeletons, the "sink" as one requiring import of carbon, the "sink strength" as the ability of a tissue or an organ to mobilize photo-assimilates, the "sink capacity (or sink size)" as the capacity of a tissue or organ to import and store further compounds from the source(s) and the "sink activity" by the rate of respiration. The source-sink relationship determines crop yield, and it is largely regulated

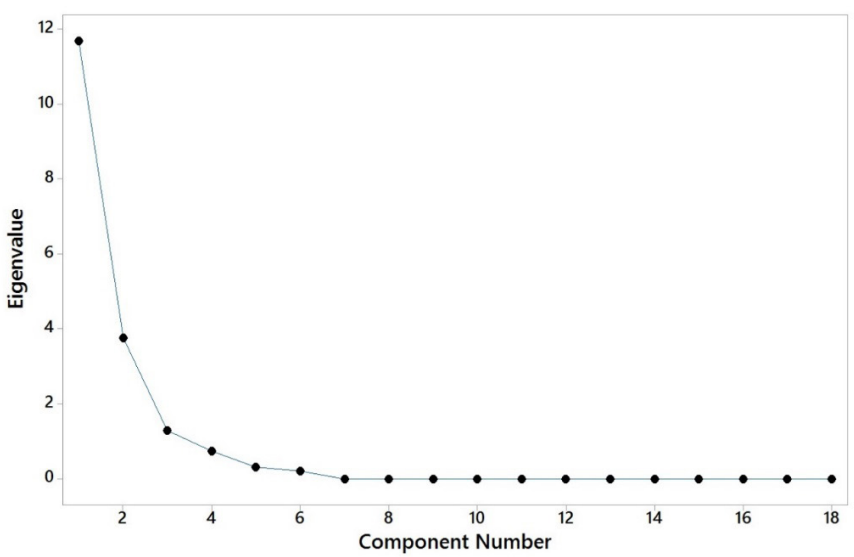

6: Scree plot showing eigenvalues in response to number of components for the estimated variables of chickpea

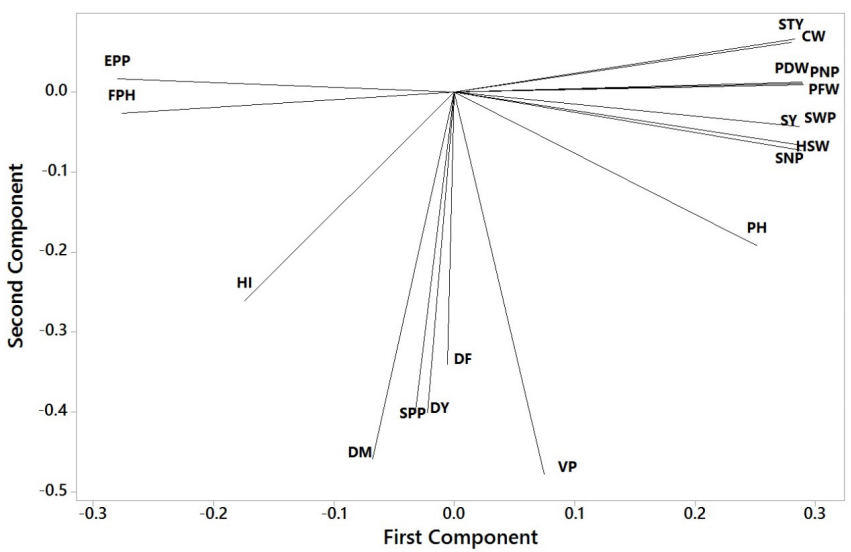

7: Plot of the first two PCAs showing relation among various traits in chickpea. $P H=$ plant height at maturity, FPH: firs pod height, DF: days to $50 \%$ flowering, VP: vegetative period, CW: canopy width, DY: day to yellowing, DM: days to maturity, PFW: plant fresh weight, PDW: plant dry weight, SNP: seed number per plant, SPP: seed number per pod, SWP: seed weight in plant, HSW: hundred seed weight, PNP: pod number per plant, EPP: empty pod per plant, SY: seed yield, HI: harvest index, STW: straw yield. 
by water and nutrients in agricultural production (Foyer and Paul, 2001). It has been reported that there is a positive significant relationship between length of vegetative phase and seed yield (Sadras and Calderini, 2009). This finding corroborates the result of Janmohammadi et al. (2014) who found that farm-yard manure significantly increased the characteristics regarding the size and strength of the source.

The dominant soils of semi-arid region are inherently infertile due to low, sporadic and variable precipitation, moisture stress, poor ground coverage, low amount of plant residues, overgrazing, degradation of organic material, deficiencies/imbalances in nutrients, low cation exchange capacity, poor aeration, high $\mathrm{pH}$ (alkalinity), salinity, impermeability, shallowness, textural problems (crusting, hardening, stoniness), high temperature (Sivakumar et al., 2013 ). In neutral to alkaline soils of semi-arid region, where chickpea is usually grown, $\mathrm{Zn}$ and Fe deficiencies is prevalent. Our results about positive effects of micronutrients are in line with findings of Janmohammadi et al. (2012) who reported that both vegetative and grain yield of chickpea increased by application of micronutrient ( $\mathrm{Fe}$ and $\mathrm{Zn}$ ) and bio-fertilizer inoculation.

In this study comparison of the plants growth under control and micronutrients utilized condition indicated that the soil of studied area is faces with both $\mathrm{Fe}$ and $\mathrm{Zn}$ deficiencies. Although the deficiencies of micronutrients in semi-arid regions is approximately prevalent and widespread, limited researches have been published on approaches for improving the efficiency of micronutrient fertilizers and increasing their availability in soil. Although the soil of semi-arid areas suffer a serious micronutrient deficiency, the results showed that the use of micronutrient fertilizers in poor soil with low SOM has little positive effect. This also accords with our earlier observations, which revealed that the supply of critical level of organic matter is necessary for achieving to economic yield and is essential for emerging of the positive effects of other inputs (Janmohammadi et al., 2016).

The results of cluster analysis revealed that the effects of $\mathrm{Fe}$ and $\mathrm{Zn}$ on agronomic traits were largely similar and this imply the severe deficiency of both elements in the soil. Then, the utilization of fertilizers containing different micronutrients is strongly recommended to achieve the potential yield. Furthermore our finding showed that integrated application of organic and micronutrients fertilizer significantly improved the efficiency of chemical fertilizers. The findings are consistent with those of Yang et al. (2011) who reported that organic manure combined with chemical fertilizer application reduced soil bulk density, increased total porosity, improved soil water retention, and decreased unsaturated hydraulic compared with application of only chemical fertilizer. Organic fertilizer play critical role in the improvement of soil structure, aeration and water holding capacity. Also, it stimulates the activity of microorganisms and it may increase nutrient solubility, decrease soil salinity and sodicity and regulate $\mathrm{pH}$ (Sheta et al., 2003).

Although the root of the chickpea has the ability to nitrogen fixation, a glancing comparison of number of nodes on roots in different organic fertilizer level indicated that the lowest nod number was related to plant grown under no-application of organic fertilizer. Micronutrients are essential for the biological nitrogen fixation process. Our results demonstrated that there is synergic effects between organic and inorganic fertilizers. Increasing effect integrated application of organic and inorganic fertilizer on soil enzyme activities has been reported by Liu et al. (2017). Soil enzymes activities are introduced as biological indicators of soil health. This confirmed that organic fertilizer, due to its high level of organic C, was more favorable for increasing soil organic C in a short term (Elzobair et al., 2016). Our

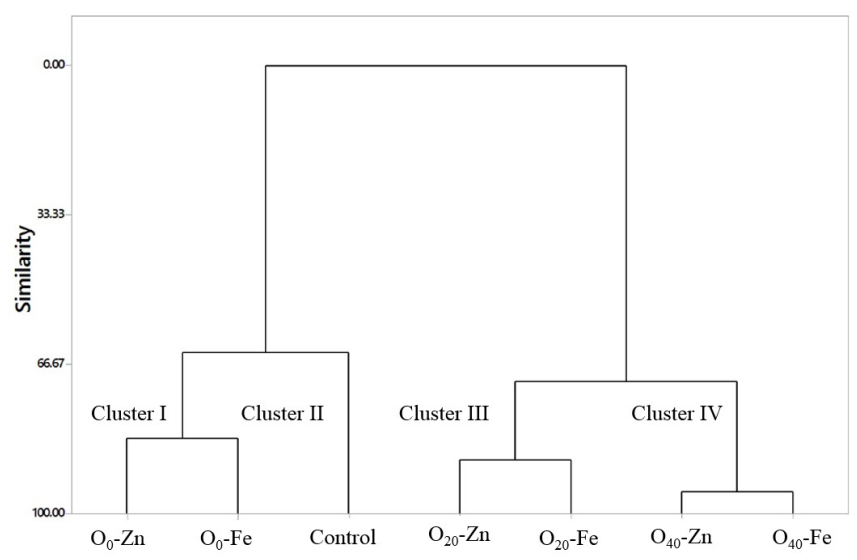

8: Cluster analysis of combined treatments (organic fertilizer and micronutrients) According to similarity in effects on morphophysiological traits of chickpea. O0: without organic fertilizer, O20: 20 t ha - 1 organic fertilizer, O40: 40 t ha - 1 organic fertilizer. Control: without application of organic and micronutrients fertilizers. 
finding is in agreement with Liu et al. (2017) findings which showed Organic fertilizer had more favorable impacts on nutrient availability and microbial activity and typically increased rice yield compared to the chemical fertilizer.

However, the environmental fate of micronutrients and their availability to plants are controlled by a diversity of soil variables such as $\mathrm{pH}$, organic matter, calcium carbonate content, cation exchange capacity (Najafi-Ghiri et al., 2013). Some of the physicochemical characteristics of the soil in semi-arid regions may lead to the fixation of micronutrients. Accordingly sustainable nutrient use efficiency could be attained by rational agronomic managements which take into account timely synchronization of nutrient application with plant roots development, or use of slowrelease fertilizers, and foliar feeding (Sheta et al., 2003; SelvaPreetha et al., 2014).

Overall findings showed that in studied area modern agriculture based on only chemicals fertilizer will not be prosperous because of many problems such as poor soil condition, imbalanced nutrients, surface and ground water pollution from fertilizers and sediments impending shortages of non-renewable resources and low farm income from high production costs (Joshi et al., 2016). However, there is increasing awareness of the need for corrections in nutritional management in chickpea production system in semi-arid region. Although, chemical micronutrient fertilizers are playing a crucial role to meet the nutrient requirement of the crop, using them in poor soil conditions will not be fruitful. Therefore, there is an urgent need to reduce the usage of chemical fertilizers and subsequently increase the application of organic fertilizers. Integrated application of micronutrient and organic fertilizers, helps to improve different aspect of soil properties and can result in higher and sustainable seed yield.

\section{CONCLUSION}

The finding of current study showed that seed yield, straw yield and harvest index affected by organic fertilizer application. Although the organic fertilizer improved the both seed and vegetative growth, its positive effects on vegetative growth was more impressive that the lowest harvest index was recorded under application of $20 \mathrm{tha}^{-1}$ organic fertilizer. Finding revealed that the positive effect of organic fertilizer on chickpea productivity was more prominent than micronutrient fertilizers. In spite of the some improving effects of $\mathrm{Fe}$ and $\mathrm{Zn}$ on growth and yield component, their best effect was observed under integrated application with organic fertilizer. Based on findings of study, it can be recommended that application of multi-micronutrients along with high level of organic fertilizer is feasible for enhancing yield of chickpea economically under agro-climatic conditions of North West of Iran. The majority of the farmers adopt this crop under limited resource conditions and unbalanced nutrition, therefore the integrated application of organic fertilizer and inorganic fertilizers in realistic and affordable doses is necessary for the sustainable chickpea production. The results showed that increasing the efficiency of micronutrient fertilizers in semi-arid conditions requires the improvement of soil physical-chemical properties.

\section{Acknowledgments}

This work was financially supported by a grant from the Ministry of Science, Research and Technology (Iran). The authors also thank the supports of the research council of the University of Maragheh.

\section{REFERENCES}

BOT, A. and BENITES, J. 2005. The importance of soil organic matter: key to drought-resistant soil and sustained food production. FAO Soils Bulletin 80. Rome: Food \& Agriculture Organization UN.

ELZOBAIR, K. A., STROMBERGER, M. E., IPPOLITO, J. A. and LENTZ, R. D.2016. Contrasting effects of biochar versus manure on soil microbial communities and enzyme activities in an Aridisol. Chemosphere, 142: 145-152.

EVERITT, B. S. and DUNN, G. 1992. Applied Multivariate Data Analysis. New York, NY: Oxford University Press; FAO. 2014. FAOSTAT Emissions database. Agriculture: FAO Statistics Division Working Paper Series, 14/01. Rome, Italy: UN FAO.

FOYER, C. H., PAUL, M. J. 2001. Source-sink relationships. In: eLS Encyclopedia of Life Sciences. Nature Publishing Group, pp. 1-11.

HENG, L. K., CAI, G., RAMANA, M. V., SACHDEV, M. S., RUSAN, M. M., SIJALI, I. V. and ISSAKA, M. 2005. The effect of soil fertility, crop management on carbon-isotope discrimination and their relationships with yield and water-use efficiency of crops in semi-arid and arid environments. In: Nutrient and water management practices for increasing crop production in rainfed arid/semi-arid areas. Proceedings of a coordinated research project, Iaea-Tecdoc-1468, pp. 15-41.

JACKSON, M. L. 1973. Methods of Soil Chemical Analysis. New Delhi: Prentice Hall of India Pvt. Ltd. 
JANMOHAMMADI, M. 2015. Evaluation of the impact of chemical and biological fertilizer application on agronomical traits of safflower (Carthamus tinctorius L.). Proceedings of the Latvian Academy of Sciences. Section B. Natural, Exact, and Applied Sciences, 69(6): 331-335.

JANMOHAMMADI, M., AMANZADEH, T., SABAGHNIA, N. and ION, V. 2016. Effect of nano-silicon foliar application on safflower growth under organic and inorganic fertilizer regimes. Botanica Lithuanica, 22(1): 53-64.

JANMOHAMMADI, M., JAVANMARD, A. and SABAGHNIA, N. 2012. Influences of micro-nutrients (zinc and iron) and bio-fertilizer on yield and yield components of chickpea (Cicer arietinum L.) cultivars. Agriculture $\sigma$ Forestry, 57(3): 53-66.

JANMOHAMMADI, M., NASIRI, Y., ZANDI, H., KOR-ABDALI, M. and SABAGHNIA, N. 2014. Effect of manure and foliar application of growth regulators on lentil (Lens culinaris) performance in semi-arid highland environment. Botanica Lithuanica, 20(2): 99-108.

JANMOHAMMADI, M., SABAGHNIA,N., SEIFI, A. andPASANDI, M. 2017. The Impacts of NanoStructured Nutrients on Chickpea Performance under Supplemental Irrigation. Acta Universitatis Agriculturae et Silviculturae Mendelianae Brunensis, 65(3): 859-870.

JOSHI, D., GEDIYA, K. M., PATEL, J. S., BIRARI, M. M. and GUPTA, S. 2016. Effect of organic manures on growth and yield of summer cowpea [Vigna unguiculata (L.) Walp] under middle Gujarat conditions. Agricultural Science Digest, 36(2): 134-137.

JU, X. and CHRISTIE, P. 2011 Calculation of theoretical nitrogen rate for simple nitrogen recommendations in intensive cropping systems: A case study on the North China Plain. Field Crops Research, 124(3): 450-458.

KARLEN, D., MAUSBACH, M., DORAN, J., CLINE R. and HARRIS, R. 1997. Soil quality: A concept, definition, and framework for evaluation (a guest editorial). Soil Science Society of America Journal, 61: 4-10.

LIU, Z., RONG, Q., ZHOU, W. and LIANG, G. 2017. Effects of inorganic and organic amendment on soil chemical properties, enzyme activities, microbial community and soil quality in yellow clayey soil. PloS one, 12(3): e0172767.

MACHADO, R. M. A., and SERRALHEIRO, R. P. 2017. Soil salinity: effect on vegetable crop growth. management practices to prevent and mitigate soil salinization. Horticulturae, 3(2): 30.

MADER, P., FLIESSBACH, A., DUBOIS, D., GUNST, L. and FRIED, P. 2002 Soil fertility and biodiversity in organic farming. Science, 296: 1694-1697.

MARSCHNER, H. 2012. Marschner's Mineral Nutrition of Higher Plants. $2^{\text {nd }}$ Edition. Amsterdam: Elsevier Ltd.

NAJAFI-GHIRI, M., GHASEMI-FASAEI, R. and FARROKHNEJAD, E. 2013. Factors affecting micronutrient availability in calcareous soils of Southern Iran. Arid Land Research and Management, 27(3): 203-215.

OLSEN, R. 1978. Effects of intensive fertilizer use on the human environment: a summary review. FAO Soils Bulletin, 116: 15-33.

SABAGHNIA, N., AHADNEZHAD, A. and JANMOHAMMDI, M. 2015. Genetic variation in garden cress (Lepidium sativum L.) germplasm as assessed by some morphological traits. Genetic Resources and Crop Evolution, 5(62): 733-745.

SADRAS, V. O. and CALDERINI, D. 2009. Crop physiology: applications for genetic improvement and agronomy. Academic Press.

SATYANARAYANA, V., VARA PRASAD, P. V., MURTHY V. R. K. and BOOTE, K. J. 2002. Influence of integrated use of farmyard manure and inorganic fertilizers on yield and yield components of irrigated lowland rice. Journal of Plant Nutrition, 25(10): 2081-2090.

SELVA PREETHA, P., SUBRAMANIAN, K. S. and SHARMILA RAHALE, C. 2014. Sorption characteristics of nanozeolite based slow release sulphur fertilizer. International Journal of Development Research, 4(2): 225-228.

SIVAKUMAR, M. V., LAL, R., SELVARAJU, R. and HAMDAN, I. 2013. Climate change and food security in West Asia and North Africa. Dordrecht: Springer.

SHETA, A. S., FALATAH, A. M., AL-SEWAILEM, M. S., KHALED, E. M. ans SALLAM, A. S. H. 2003. Sorption characteristics of zinc and iron by natural zeolite and bentonite. Microporous and Mesoporous Materials, 61(1): 127-136.

SHIRANI, H., HAJABBASI, M. A., AFYUNI, M. and HEMMAT, A. 2002. Effects of farmyard manure and tillage systems on soil physical properties and corn yield in central Iran. Soil and Tillage Research, 68(2): 101-108.

SNYDER, K.A. and TARTOWSKI, S. L. 2006. Multi-scale temporal variation in water availability: implications for vegetation dynamics in arid and semi-arid ecosystems. Journal of Arid Environments, 65(2): 219-234.

TANDON, H. L. S. (Ed.). 1995. Methods of analysis of soils, plants, waters and fertilisers. New Delhi, India: Fertilisers Development and Consultation Organisation.

WANG, Z. G., JIN, X., BAO, X. G., LI, X. F., ZHAO, J. H., SUN, J. H. and LI, L. 2014. Intercropping enhances productivity and maintains the most soil fertility properties relative to sole cropping. PloS one, 9(12):el13984.

YADAV, S. S., REDDEN, R. J., CHEN, W. and SHARMA, B. 2007 Chickpea Breeding and Management. Oxfordshire, UK: CAB International. 
YANG. X. Y., LI, P. R., ZHANG, S. L., SUN, B. H. and CHEN, X. P. 2011. Longterm-fertilization effects on soil organic carbon, physical properties, and wheat yield of a loess soil. Journal of Plant Nutrition and Soil Science, 174: 775-784.

Mohsen Janmohammadi:jmohamad@ut.ac.ir

Contact information 